\title{
Palaemon elegans, an intermediate host in the life-cycle of Aggregata octopiana
}

\author{
C. Arias, C. Gestal, H. Rodríguez, M. Soto, J. Estévez* \\ Laboratorio de Parasitología, Facultad de Ciencias del Mar, Universidad de Vigo, Apartado 874, E-36200 Vigo, Spain
}

\begin{abstract}
Based on immunological methods, the prawn Palaemon elegans apparently acts as the natural intermediate host for Aggregata octopiana, a coccidian that infects the cephalopod Octopus vulgaris. However, cross-reactivity with another coccidian, A. eberthi, was present in both sporogonic and merogonic stages.
\end{abstract}

KEY WORDS: Aggregata octopiana $\cdot$ Life cycle Palaemon elegans

Coccidians of the genus Aggregata cause major diseases in cephalopods. The merozoites migrate through the epithelium of the digestive tract causing degeneration and death of the parasitized cells and leading to detachment of necrotic fragments of the intestine (Hochberg 1990). Despite their importance, reliable information currently exists only about the life-cycle of the species A. eberthi Labbé, 1895, a coccidian parasite of crabs and cuttlefish. As in some other coccidians, there is alternation of generations and alternation of hosts. In both hosts, the parasites are found in the intestinal epithelium or wall. The asexual phase is in the peri-intestinal tissue of Portunus depurator L., 1758 while the sexual phase occurs within cells of the submucous connective tissue of the caecum and intestine of Sepia officinalis L. 1758 (Dobell 1925).

The cephalopod Octopus vulgaris Cuvier, 1789 is the definitive host for the species Aggregata octopiana Schneider, 1875 (Estévez et al. 1996). This paper presents the first report of the prawn Palaemon elegans Rathke, 1837 as intermediate host in the life-cycle of this coccidian.

Materials and methods. Prawns and parasites: Fortyeight crustaceans belonging to the species Palaemon

\footnotetext{
-Addressee for correspondence. E-mail: jestevez@uvigo.es
}

elegans (Decapoda: Palaemonidae) (Haywar \& Ryland 1985) were caught in the Ría de Vigo (NW Spain) and dissected. Their digestive tracts were extracted and examined under the stereo microscope in order to detect cysts. Oocysts of Aggregata octopiana and $A$ eberthi were isolated from the digestive tracts of the naturally infected molluscan cephalopods Octopus vulgaris and Sepia officinalis, respectively, in the Ría de Vigo (Estévez et al. 1996, Pascual et al. 1996).

Purification of sporocysts and preparation of sporocyst extracts: Sporocysts of Aggregata octopiana and $A$. eberthi were purified from oocysts. Briefly, sporocysts were obtained by maceration of infected, cephalopod host tissues in phosphate-buffered saline (PBS), pH 7.2. The resulting suspension was then filtered through increasingly fine meshes to remove tissue fragments. The filtrate was then centrifuged at $2000 \times g$ for $15 \mathrm{~min}$. Filtration-centrifugation of the pellet was repeated several times until a pure sample of sporocysts was obtained. Sporocysts were lysed by sonication on ice ( $60 \mathrm{~W}$ in $1 \mathrm{~min}$ pulses for $45 \mathrm{~min}$ ) and centrifuged at $10000 \times g$ for $30 \mathrm{~min}$ at $4^{\circ} \mathrm{C}$. The supernatant (used in all analyses) was stored at $-30^{\circ} \mathrm{C}$ until used (Leiro et al. 1993).

Collection of sera: Ten female Balb/c mice were immunized by subcutaneous injection of a $0.2 \mathrm{ml} \mathrm{mix-}$ ture of Freund's complete adjuvant (Sigma Chemical Co., St. Louis, MO, USA) and PBS containing about $5 \times 10^{6}$ sporocysts of Aggregata octopiana. They were boostered $30 \mathrm{~d}$ later by intraperitoneal (i.p.) injection of the same number of sporocysts in $0.2 \mathrm{ml}$ of PBS without adjuvant. On Day 45 a third dose (without adjuvant) was administered by i.p. injection. Mice were bled $60 \mathrm{~d}$ after primary immunization through the retroorbital route. Serum (anti-Aggregata octopiana) was separated by centrifugation at $2000 \times g$ for $10 \mathrm{~min}$, mixed $1: 1$ with glycerol and stored at $-30^{\circ} \mathrm{C}$ until use. A similar protocol was used to obtain anti-A. eberthi serum. 


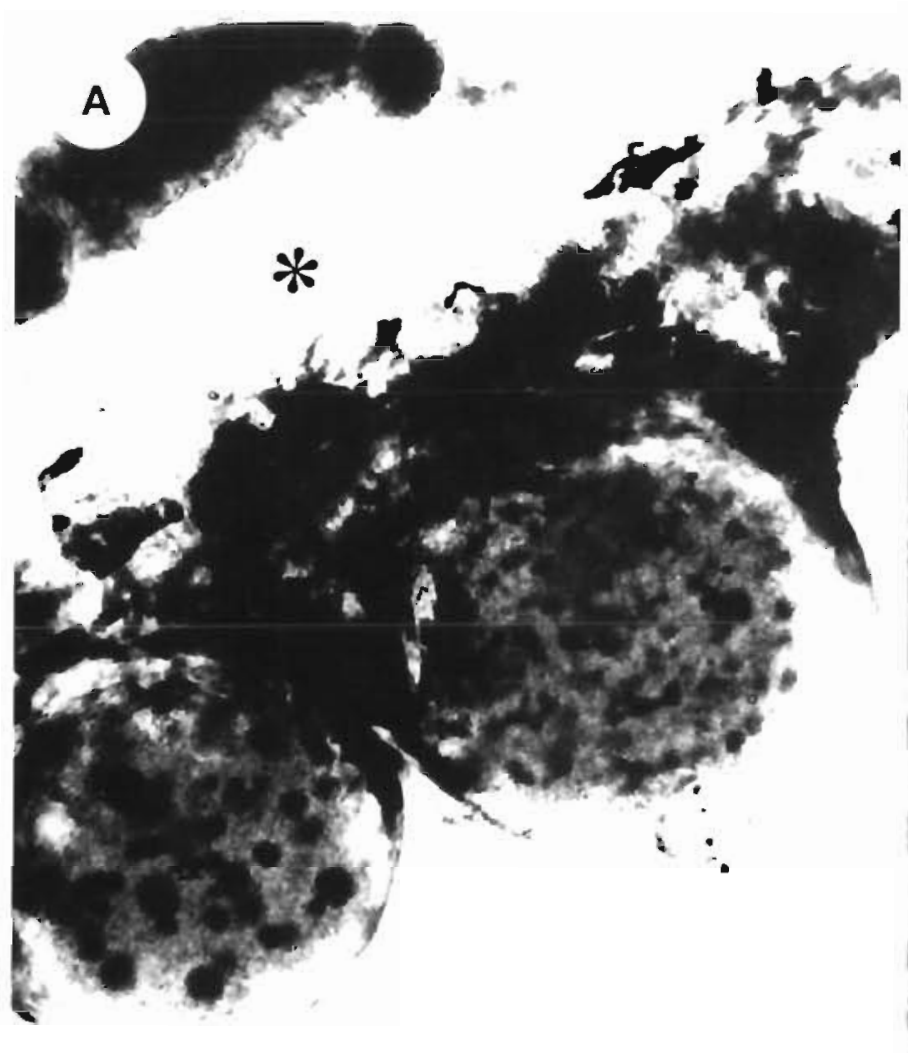

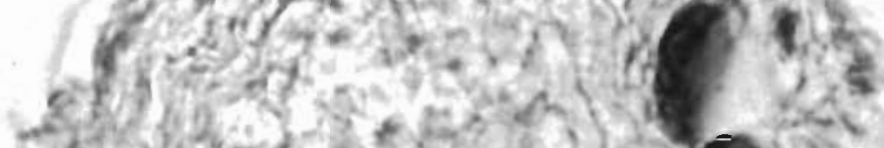

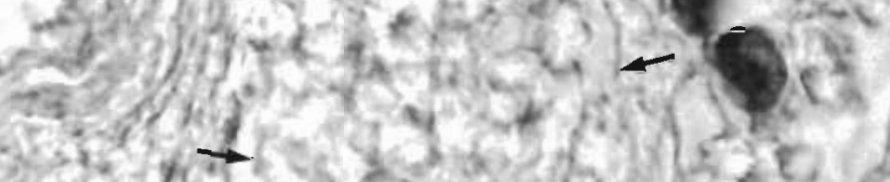
the $y$. ond

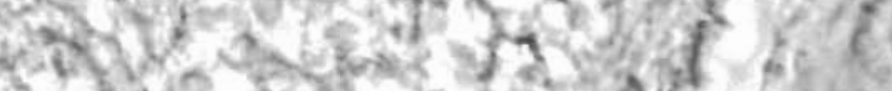

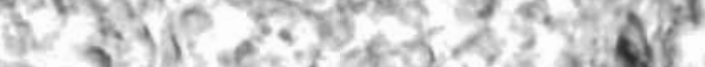

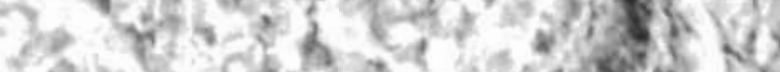

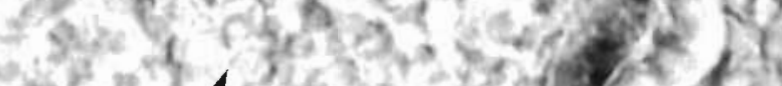

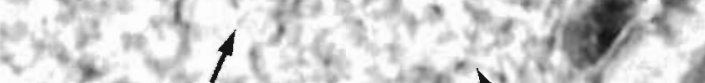

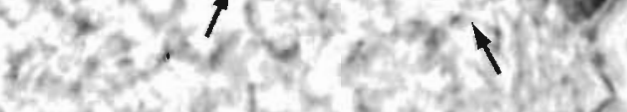

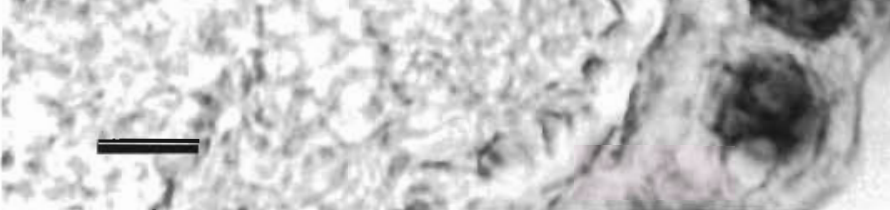
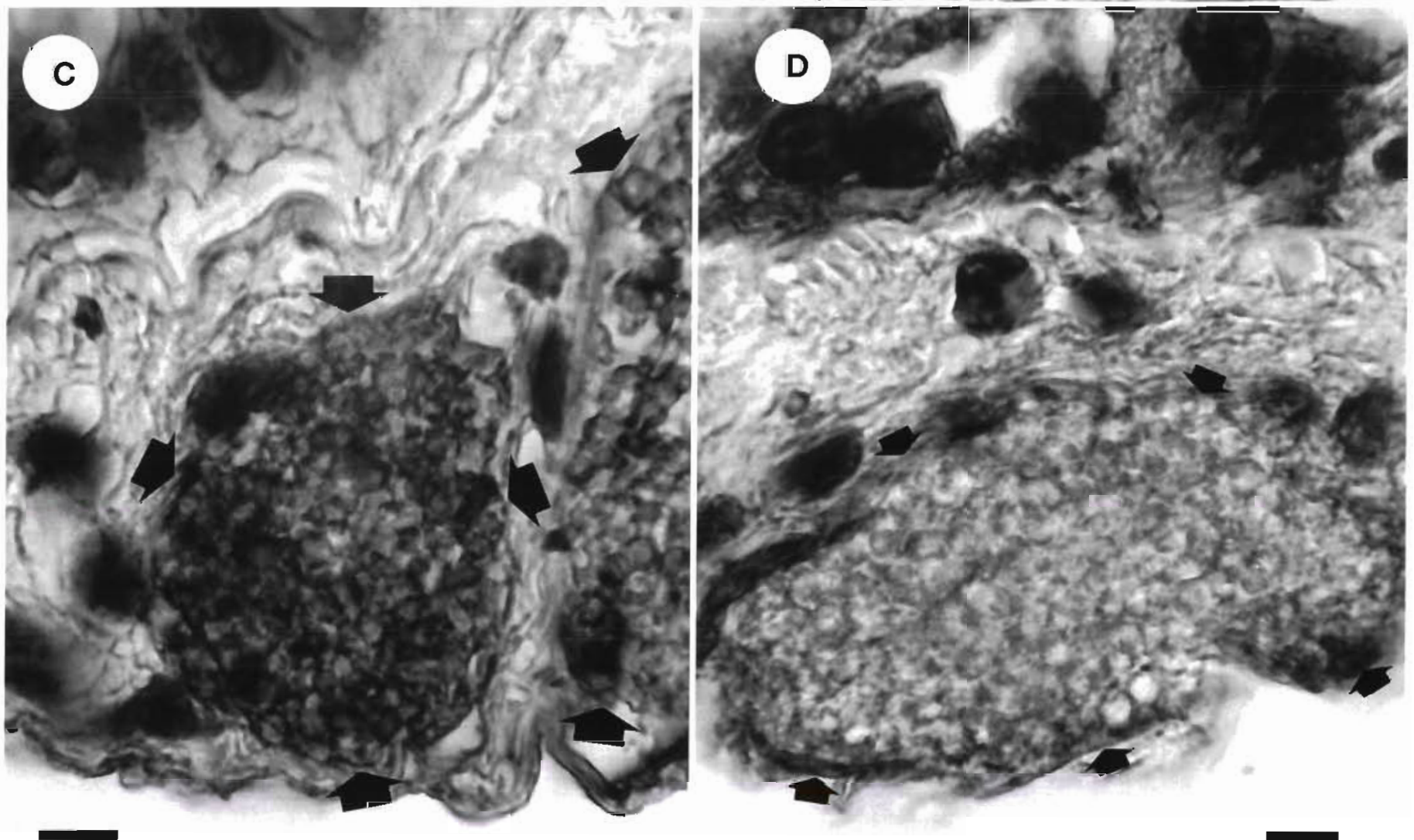
Fig. 1. Palaemon elegans. (A) Segment of the gut of the prawn Palaemon elegans showing the intestine (*) and cysts with multiple nuclei arranged in the cytoplasm. Scale bar $=100 \mu \mathrm{m}$. (B-D) Section of a cyst in prawn gut tested with: (B) normal mouse serum, background level, (arrows indicate the cyst location): (C) anti-Aggregata octopiana mouse serum (arrows indicated the area of strong positive reaction), and (D) anti - $A$. eberthi mouse serum (arrows indicate the area of slight reaction). Haematoxylin was used as the counterstain. Scale bar $=10 \mu \mathrm{m}$

Slide pre-processing: Infected intestines from the crustacean Palaemon elegans were kept in $10 \%$ formaldehyde in PBS, pH 7.2, for 12 to $24 \mathrm{~h}$. The samples were dehydrated in increasing concentrations of ethanol and embedded in paraffin wax, after which $4 \mu \mathrm{m}$ microtome sections were cut, dewaxed and mounted.

Immunohistochemistry: Immunohistochemistry was performed by the indirect immunoperoxidase method (Tijsen 1987). Mounted sections were incubated for $30 \mathrm{~min}$ in $10 \% \mathrm{H}_{2} \mathrm{O}_{2}$ in Tris-buffered saline (TBS: $50 \mathrm{mM}$ Tris, $0.15 \mathrm{M} \mathrm{NaCl}, \mathrm{pH} 7.4$ ) to inhibit endogenous peroxidase. They were then washed with TBS and incubated for $1 \mathrm{~h}$ with $5 \%$ non-fat dry calf milk in TBS containing $0.2 \%(\mathrm{v} / \mathrm{v})$ Tween-20 (TBS-Tween) at room temperature (RT) to block non-specific reactions. After being washed with TBS-Tween, the slides were incubated with a 1:20 dilution of the primary sera (antiAggregata octopiana or anti-A. eberthi) in TBS-Tween for $4 \mathrm{~h}$ at RT in a humid chamber. Next, they were washed with TBS-Tween and incubated for $1 \mathrm{~h}$ with polyclonal rabbit anti-mouse immunoglobulin serum (Dakopats A/S, Glostrup, Denmark) diluted 1:100 in TBS-Tween. The slides were then washed with TBS and incubated with $100 \mu$ l substrate solution of TBS containing $0.003 \% \quad \mathrm{H}_{2} \mathrm{O}_{2}, \quad 0.06 \%$ diaminobenzidine tetrahydrochloride (Sigma) and $0.03 \% \mathrm{NiCl}_{2}$. After a brown colour had developed, the reaction was stopped by washing the slides with TBS. The sections were then mounted in TBS-glycerol (1:1) and covered with a cover glass for photography. Appropiate negative controls were included in each case. Haematoxylin was used as the counterstain (Culling et al. 1985).
Enzyme-linked immunosorbent assay (ELISA): Titration curves were derived and the cross-reactivity of the antisera assayed was tested using the indirect ELISA technique, as described previously (Estévez et al. 1994).

Results. Immunohistochemistry: At least 1 cyst was found to be present in the peri-intestinal tissues of $63 \%$ of the natural Palaemon elegans examined. Fig. 1A shows these cysts, inside of which multiple nuclei can be seen, corresponding to the merozoites.

Intestinal sections of Palaemon elegans containing cysts were chosen for immunoassay comparisons. Negative controls used normal mouse serum (background level) which gave no reaction (Fig. 1B). In all the coccidian-infected prawns tested, the cysts containing merozoites reacted positively to anti-Aggregata octopiana sporocyst mouse serum (Fig. $1 \mathrm{C}$ ) but showed little reaction to anti-A. eberthi sporocyst mouse serum (Fig. 1D).

Cross-reactivity study: ELISA was used to determine the titer of the 2 polyclonal antisera, which was estimated at over $1: 10^{6}$ for both (Fig. 2A). Crossreactivity was also observed. Antibodies raised in mice with Aggregata eberthi purified sporocysts crossreacted with sporocyst extracts of $A$. octopiana (heterologous antigen) (Fig. 2B).

Discussion. Polyclonal antisera are effectively applied in taxonomic studies on protozoa (McGovern \& Burreson 1989, Martín-González et al. 1991) and here we used them to identify the intermediate host in the cycle of Aggregata octopiana.

Immunoassay of the prawn tissues indicated that mouse anti - Aggregata octopiana sporocyst serum gave a strong positive reaction to cysts (merozoites) found in
Fig. 2. (A) Titration curves for ELISA assays of sporocyst antisera. (ם) Anti-Aggregata octopiana sporocyst mouse serum; (0) anti-A. eberthi sporocyst mouse serum. Background level (normal mouse serum) is represented by the dotted line. Values are expressed as $\log _{2}$ of the antibody dilution with initial dilution 1:500. (B) Cross-reactivity of the antisera assayed (at dilution 1:20000) with antigen extracted from $A$. octopiana sporocysts. White bar: anti-A. octopiana sporocyst serum; black bar anti- $A$. eberthi serum; hatched bar: normal mouse serum

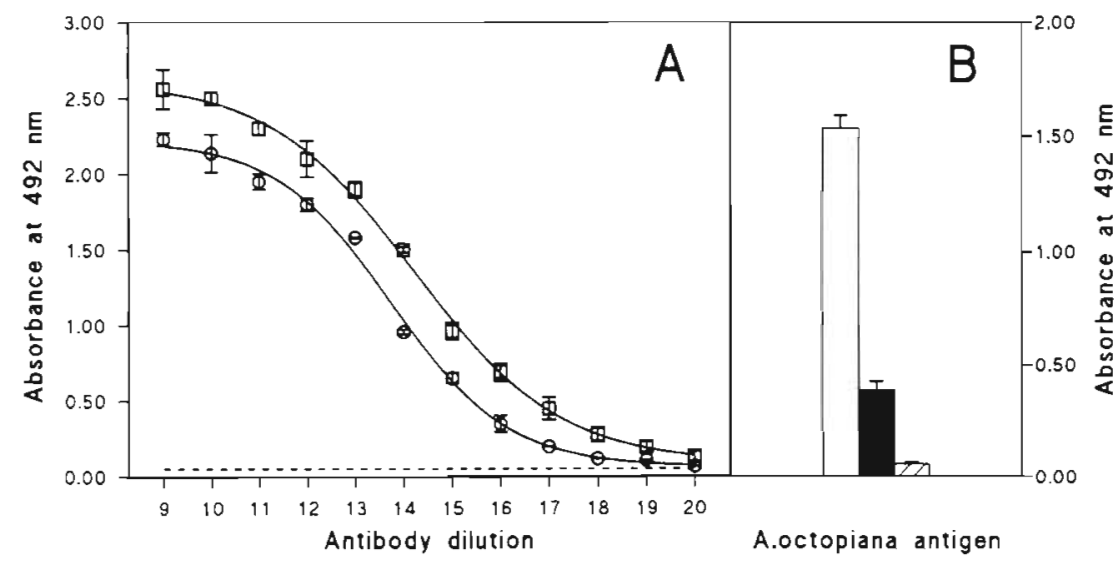


the digestive tract of Palaemon elegans. Nevertheless, a slight reaction was also observed between these cysts and mouse anti-A. eberthi sporocyst serum. Cross-reactivity between species of the same genus has already been recorded in coccidians of the genus Eimeria by Xie et al. (1992). Here, the cross-reactivity between the 2 species of Aggregata was shown to occur for 2 stages of the biological cycle (i.e. the merogony stage in the crustacean gut and the sporogony stage in the cephalopod gut).

The prevalence of cysts of Aggregata octopiana in the gut of Palaemon elegans was approximately $63 \%$, a figure which comes close to that of $75 \%$ obtained by Dobell (1925) for A. eberthi in the crab Portunus depurator. However, Dobell showed that parasitic specificity of $A$. eberthi was slight, since at least 2 species of crab belonging to the genus Portunus (mainly $P$. depurator and to a lesser extent $P$. corrugatus Pennant, 1777 ) could be intermediate hosts. We do not rule out the possibility that other prawn species of the genus Palaemon could also act as intermediate hosts for $A$. octopiana.

Acknowledgements. We thank Prof. Dr F. Ramil and O. Mijon (Laboratorio de Biología Animal, Univ. Vigo) for prawn identifications. This work was partially financed by the Spanish Government under Project CICYT-MAR 95-1919-C05-03 and the Xunta de Galicia Project XUGA 30106A96

\section{LITERATURE CITED}

Culling CFA, Allison RT, Barr WT (1985) Cellular pathology technique. Butterworth \& Co, London, p 3-180

Dobell C (1925) The life-history and chromosome cycle of Aggregata eberthi (Protozoa: Sporozoa: Coccidia). Parasitology $17: 1-136$

Editorial responsibility: Timothy Flegel,

Bangkok, Thailand
Estévez J, Leiro J, Santamarina MT, Dominguez J, Ubeira FM (1994) Monoclonal antibodies to turbot (Scophthalmus maximus) immunoglobulins: characterization and applicability in immunoassays. Vet Immunol Immunopathol 41: $353-366$

Estévez J, Pascual S, Gestal C, Soto M, Rodríguez H, Arias C (1996) Aggregata octopiana Frenzel 1885 (Apicomplexa: Aggregatidae) from Octopus vulgaris (Cuvier, 1798) off NW Spain. Dis Aquat Org 27:227-231

Haywar PJ, Ryland JS (1995) Handbook of the marine fauna of North-West Europe. Oxford University Press, Oxford

Hochberg FG (1990) Diseases of Mollusca: Cephalopoda. Diseases caused by protistans and metazoans. In: Kinne $O$ (ed) Diseases of marine animals, Vol III. Biologische Anstalt Helgoland, Hamburg, p 47-202

Leiro J, Estévez J Santamarina MT, Sanmartín ML, Ubeira FM (1993) Humoral immune response of turbot, Scophthalmus maximus (L.), to antigens from Tetramicra brevifilum Matthews \& Matthews, 1980 (Microspora). J Fish Dis $16: 577-584$

Martín-González A, Benitez Rico L, Gutierrez JC (1991) Application of a polyclonal antiserum against isolated cysts walls to the taxonomical study of ciliates. Cytobios $66: 133-142$

Mcgovern ER, Burreson EM (1989) Immunoassay comparison of Haplosporidian spores from Teredo navalis and Haplosporidium nelsoni spores from Crassostrea virginica J Protozool 36:289-292

Pascual S, Gestal C, Estévez J, Rodríguez H, Soto M, Abollo E Arias C (1996) Parasites in commercially-exploited cephalopods (Mollusca: Cephalopoda) in Spain: an updated perspective. Aquaculture 142:1-10

Tijssen P (1987). Enzyme immunohistrochemistry (EIH) in light and electron microscopy. In: Burdon RH, Knippenberg $\mathrm{PH}$ van (eds) Laboratory techniques in biochemistry and molecular biology. Practice and theory of enzyme immunoassays. Elsevier, Amsterdam, p 449-499

Xie M, Gilbert JM, McDougald LR (1992) Electrophoretic and immunologic characterization of proteins of merozoites of Eimeria acervulina, E. maxima, E. necatrix and E. tenella. J Parasitol 78:82-86

Submitted: June 11, 1997; Accepted: October 8, 1997

Proofs received from author(s): December 29, 1997 